JOURNAL OF NURSING PRACTICE AND EDUCATION VOL.2 NO. 01, DESEMBER 2021

DOI: 10.34305/inpe.v2i1.374
Ciptaan disebarluaskan di bawah Lisensi Creative Commons AtribusiNon Komersial-Berbagi Serupa 4.0

\title{
HUBUNGAN FREKUENSI DAN DURASI PENYAKIT INFEKSI DENGAN KEJADIAN STUNTING DI WILAYAH KERJA PUSKESMAS KEBASEN KABUPATEN BANYUMAS
}

\author{
Vita Hasta Lusiani, Atika Dhiah Anggraeni \\ Universitas Muhammadiyah Purwokerto \\ hastalusianivita@gmail.com
}

\begin{abstract}
Abstrak
Masa balita adalah masa golden age dimana periode dalam masa ini sangat penting untuk pertumbuhan dan perkembangan untuk kelangsungan hidup kedepannya, karena masa balita ini kelompok umur yang rawan gizi dan rawan penyakit. Masalah status gizi khususnya anak pendek (stunting) di masa yang akan datang akan mengalami kesulitan dalam mencapai perkembangan fisik dan kognitif yang optimal. Stunting juga dipengaruhi oleh beberapa faktor yaitu penyakit infeksi diantaranya diare dan ISPA. Penelitian ini untuk mengetahui hubungan frekuensi dan durasi penyakit infeksi (Diare dan ISPA) dengan kejadian stunting di wilayah kerja Puskesmas Kebasen. Penelitian ini merupakan penelitian kuantitatif Analitik Observasional dengan pendekatan case-control. Jumlah sampel 96 responden pengambilan sampel dalam penelitian ini menggunakan metode cluster sampling. Instrumen penelitian ini adalah lembar kuesioner dengan uji Chi-Square.Hasil penelitian ini bahwa usia 24-59 bulan yang mengalami penyakit diare dan ISPA yang lebih sering dan lama yaitu anak yang mengalami stuntingdibandingkan dengan anak balita normal dengan nilai frekuensi diare $\rho$ value $0,013(<0,05)$, durasidiare $\rho$-value $0,030(<0,05)$, frekuensi ISPA $\rho$-value 0,016 $(<0,05)$, durasi ISPA $\rho$-value 0,021 $(<0,05)$, dengan kejadian stunting.Terdapat hubungan antara frekuensi dan durasi penyakit infeksi (Diare dan ISPA) dengan kejadian stunting, oleh karena itu harus menjadi perhatian ibu untuk mengetahui tentang kesehatan anak terutama penanganan pertama penyakit infeksi pada balita.
\end{abstract}

Kata Kunci: Stunting, Penyakit Infeksi 
JOURNAL OF NURSING PRACTICE AND EDUCATION VOL. 2 NO. 01, DESEMBER 2021

DOI: $10.34305 /$ inpe.v2i1.374

\section{Pendahuluan}

Masa balita merupakan masa yang dikenal dengan golden age dan periode yang kritis. Hal tersebut dikarenakan masa golden age adalah masa yang sangat penting untuk memperhatikan pola tumbuh kembang anak secara cermat agar sedini mungkin dapat terdeteksi jika terjadi kelainan selama pertumbuhan dan perkembangan balita (Azrimaidaliza et al. 2019).

Kekurangan gizi merupakan salah satu yang dapat mengakibatkan anak mudah terserang penyakit. Hal ini dapat disebabkan oleh beberapa faktor diantaranya pemberian asupan makanan yang diberikan setiap harinya tidak sesuai dengan kebutuhan untuk beraktivitas. Adanya penyakit infeksi yang diderita oleh balita akan menjadikan daya tahan tubuh menurun dan berdampak pada penurunan berat badan dan kebutuhan asupan nutrisi anak tidak terpenuhi (Agung, et al. 2020).

Stunting merupakan kondisi dimana balita memiliki panjang badan atau tinggi badan yang kurang jika dibandingkan dengan umurnya. Kondisi ini diukur menggunakan panjang atau tinggi badan

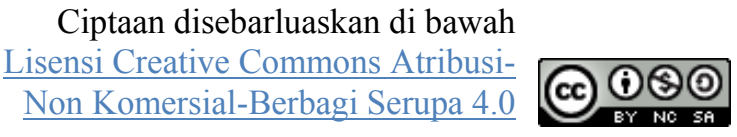

yang lebih dari minus dua standar deviasi median standar pertumbuhan anak. Balita stunting di masa yang akan datang akan mengalami kesulitan salah satunya dalam mencapai perkembangan fisik dan kognitif yang optimal (Kemenkes, 2018).

Stunting banyak terdapat pada anak dengan penyakit infeksi. Bila infeksi tersebut terjadi dalam waktu jangka panjang dan berulang maka dapat mengakibatkan pertumbuhan anak terhambat dan anak akhirnya akan menjadi pendek pada seusia normalnya.

Anak yang mempunyai riwayat penyakit ISPA biasanya ditandai dengan gejala batuk diantaranya spesifiknya yaitu pilek dan panas, keadaan tersebut akan membuat nafsu makan anak menjadi terganggu, sehingga selama sakit kebutuhan asupan nutrisi pada anak tidak terpenuhi(Rendradhuita, 2018).

Diare dapat menimbulkan terjadinya gizi kurang. Penyakit infeksi dapat mempengaruhi status gizi dengan penurunan asupan makanan, penurunan absorbsi makanan di usus, meningkatkan katabolisme dan mengambil gizi yang diperlukan tubuh untuk sintesis jaringan 
JOURNAL OF NURSING PRACTICE AND EDUCATION VOL. 2 NO. 01, DESEMBER 2021

DOI: 10.34305/inpe.v2i1.374

dan pertumbuhan. Di samping itu, gizi kurang bisa menjadi faktor predisposisi karena akan terjadinya infeksi dan menurunkan pertahanan tubuh dan mengganggu fungsi kekebalan tubuh (Angkat, 2018).

Menurut Agung, et al (2020) anak dengan umur 24-59 bulan, beberapa permasalahan umum adalah balita masih susah makan dan juga secara bersamaan kualitas dan kuantitas ASI yang semakin berkurang dengan bertambahnya umur. Sehingga sampai usia 24 bulan dianggap sebagai masa adaptasi untuk dapat mengkonsumsi makanan yang sesuai dengan zat gizi. Pada usia diatas 24 bulan balita akan mulai mampu melahap makanan lebih banyak. Maka banyak masalah gizi termasuk stunting banyak juga dialami oleh anak usia diatas 24 bulan dibandingkan 24 bulan kebawah.

Berdasarkan data yang diperoleh dari Dinas Kesehatan Kabupaten Banyumas, 2019 terdapat 39 Puskesmas yang tersebar di 27 Kecamatan, prevalensi stunting dengan total jumlah balita yang diukur tinggi badan sebanyak 103.897
Ciptaan disebarluaskan di bawah Lisensi Creative Commons AtribusiNon Komersial-Berbagi Serupa 4.0

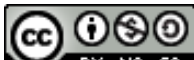

balita, tercatat sebanyak 16.581 atau $15,96 \%$ diantaranya mengalami Balita Pendek (TB/U) atau stunting.

Prevalensi stunting di wilayah kerja Puskesmas Kebasen mencapai angka $23,19 \%$ yang merupakan peringkat kedua kasus stunting tertinggi di Kabupaten Banyumas (Dinas Kesehatan Kabupaten Banyumas, 2019).Tujuan peneliti ini untuk mengetahui Hubungan Frekuensi dan Durasi Penyakit Infeksi Dengan Kejadian stunting Di Wilayah Kerja Puskesmas Kebasen Kabupaten Banyumas”.

\section{Metode}

Jenis penelitian yang digunakan dalam penelitian ini adalah observasional analitik dengan pendekatan case-control. Penelitian ini dilaksanakan pada bulan Maret-April 2021 di wilayah kerja Puskesmas Kebasen Kabupaten Banyumas dengan jumlah sampel sebanyak 96 responden. Teknik pengambilan sampel dalam penelitian ini menggunakan teknik cluster sampling. Instrumen yang digunakan berupa kuesioner (angket). Analisa data yang digunakan uji chi-square. 


\section{Hasil}

A. Hasil Penelitian

1. Analisis Univariat

a. Karakteristik Responden

Tabel 1.1 Distribusi Karakteristik responden Ibu dan Balita

\begin{tabular}{|c|c|c|c|c|}
\hline \multirow[t]{2}{*}{ Karakteristik } & \multicolumn{2}{|c|}{$\begin{array}{l}\text { Kasus } \\
\text { (Balita stunting) }\end{array}$} & \multicolumn{2}{|c|}{$\begin{array}{l}\text { Kontrol } \\
\text { (Balita Normal) }\end{array}$} \\
\hline & $\mathbf{N}$ & $\%$ & $\mathbf{N}$ & $\%$ \\
\hline \multicolumn{5}{|l|}{ Karakteristik balita } \\
\hline \multicolumn{5}{|l|}{ Usia } \\
\hline 24-35 bulan & 23 & 47,9 & 26 & 54,2 \\
\hline 36-47 bulan & 18 & 37,5 & 12 & 25,0 \\
\hline 48-59 bulan & 7 & 14,6 & 10 & 20,8 \\
\hline \multicolumn{5}{|l|}{ JenisKelamin } \\
\hline Perempuan & 21 & 43,8 & 25 & 52,1 \\
\hline Laki-laki & 27 & 56,3 & 23 & 47,9 \\
\hline \multicolumn{5}{|l|}{ Pemberian ASI } \\
\hline Parsial & 24 & 50,0 & 18 & 37,5 \\
\hline Predominan & 4 & 8,3 & 5 & 10,4 \\
\hline Eksklusif & 20 & 41,7 & 25 & 52,1 \\
\hline \multicolumn{5}{|l|}{ Karakteristik ibu } \\
\hline \multicolumn{5}{|l|}{ Pendidikan } \\
\hline SD & 18 & 37,5 & 11 & 22,9 \\
\hline SMP & 13 & 27,1 & 16 & 33,3 \\
\hline SMA & 15 & 31,3 & 16 & 33,3 \\
\hline Perguruan Tinggi & 2 & 4,2 & 5 & 10,4 \\
\hline \multicolumn{5}{|l|}{ Pekerjaan } \\
\hline Ibu Rumah Tangga & 32 & 66,7 & 30 & 62,5 \\
\hline Pegawai Negri & 2 & 4,2 & 2 & 4,2 \\
\hline Pegawai Swasta & 10 & 20,8 & 13 & 27,1 \\
\hline Wiraswasta & 4 & 8,3 & 3 & 6,3 \\
\hline \multicolumn{5}{|l|}{ Usia Ibu } \\
\hline 20-35 tahun & 28 & 58,3 & 32 & 66,7 \\
\hline 36-40 tahun & 20 & 41,7 & 16 & 33,3 \\
\hline
\end{tabular}

Berdasarkan hasil penelitian pada karakteristik jenis usia lebih banyak terjadi pada usia 24-35 bulan. Dalam usia ini pertumbuhan dan perkembangan balita sangat cepat dan membutuhkan asupan makanan yang bergizi seimbang untuk proses tumbuh kembang balita. Menurut penelitian Welasih\& Wirjatmadi (2012) menyimpulkan jumlah balita stunting lebih banyak pada usia lebih dari 24 bulan. Hal 
JOURNAL OF NURSING PRACTICE AND EDUCATION VOL. 2 NO. 01, DESEMBER 2021

DOI: $10.34305 /$ inpe.v2i1.374

ini terjadi karena pertumbuhan anak terjadi secara optimal mulai dari tahun pertama kehidupan sampai dengan tahun kedua dan kejadian stunting pada tahun kedua yang terjadi merupakan dampak bersifat kronis yang tampak akibat dari kondisi kurangnya asupan gizi pada saat usia di bawah 25 bulan.Pada karakteristik balita berdasarkan jenis kelamin terbanyak adalah laki-laki sebanyak 50 responden.

Hasil penelitian ini sejalan dengan penelitian yang dilakukan oleh menurut Christin, et al. (2018) terdapat hubungan yang bermakna antara jenis kelamin dengan kejadian stunting, karena pada jenis kelamin menentukan besarnya kebutuhan gizi bagi seseorang sehingga terdapat keterkaitan antara status gizi dengan stunting.Berdasarkan hasil penelitian pada karakteristik pemberian ASI adalah pada kelompok kasus terbanyak adalah pemberian ASI Parsial sebanyak 24 responden.

Hal ini juga sejalan dengan penelitian Noorhasanah, et al. (2020) dengan hasil penelitiannya yaitu balita dengan stunting lebih banyak pada pemberian ASI Parsial karenapemberian ASI yang tidak eksklusif akan menjadi

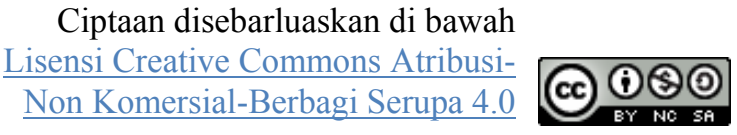

salah satu penyebab terjadinya stunting pada balita. ASI eksklusif merupakan makanan pertama dan utama pada usia bayi $>6$ bulan hingga sampai bayi pada saat berusia $>6$ bulan untuk pemenuhan gizi untuk mencegah terjadinya stunting. Berdasarkan hasil penelitian Pada karakteristik pendidikan ibu pada kelompok kasus terbanyak adalah lulusan SD sedangkan kelompok kontrol adalah SMP/SMA. Pendidikan ibu pada kelompok kasus masih rendah dibandingkan kelompok kontrol.

Menurut Maradzika, et al. (2016) dalam penelitiannya menyebutkan bahwa ibu yang berpendidikan tinggi akan membuat keputusan untuk meningkatkan asupan gizi yang seimbang dan dapat meningkatkan kesehatan dan dapat memperhatikan perkembangan dan pertumbuhan pada anak. Ibu yang memiliki tingkat pendidikan yang tinggi harapannya juga dapat meningkatkan keuangan keluarga sehingga dapat meningkatkan pendapatan keluarga dan dapat membuat status asupan nutrisi yang lebih baik.

Pada karakteristik berdasarkan pekerjaan ibu adalah terbanyak adalah tidak bekerja yaitu 62 responden, bekerja 34 
JOURNAL OF NURSING PRACTICE AND EDUCATION VOL. 2 NO. 01, DESEMBER 2021

DOI: 10.34305/inpe.v2i1.374

responden. Hal tersebut menunjukkan bahwa ibu yang tidak bekerja lebih banyak dibandingkan dengan ibu yang bekerja.

Hal ini sesuai dengan penelitian dari Arini, et al.(2020) menyimpulkan bahwa kejadian bayi dengan stunting lebih banyak terjadi dengan ibu yang tidak bekerja dibandingkan dengan ibu yang memiliki pekerjaan, karena ibu dengan status bekerja dapat membantu perekonomian keluarga sehingga dapat meningkatkan daya beli ibu untuk pembelian asupan nutrisi yang adekuat dan seimbang untuk proses pertumbuhan. Meskipun waktu pola asuh ibu pada anak lebih sedikit dibandingkan
Ciptaan disebarluaskan di bawah Lisensi Creative Commons AtribusiNon Komersial-Berbagi Serupa 4.0 dengan pola asuh ibu yang tidak bekerja. Berdasarkan hasil penelitian pada karakteristik ibu tingkatan usia ibu terbanyak yaitu 20-35 tahun.

Penelitian yang serupa dikemukakan oleh (Manggala, et al.(2018) menyebutkan bahwa dimana usia ibu yang masih muda $<20$ tahun dan usia terlampau tua $>35$ tahun memiliki hubungan yang signifikan dengan kejadian stunting dan 4 kali lebih dibandingkan dengan umur 20-35 tahun karena usia dapat menggambarkan kematangan berfikir dan dapat memperhatikan dalam melakukan pengasuhan terbaik terhadap balita.

b. Deskripsi Variabel Penelitian Frekuensi dan Durasi (Diare dan ISPA)

Tabel 1.2 Distribusi Frekuensi dan Durasi dengan Kejadian Stanting di Wilayah Kerja Puskesmas Kebasen Kabupaten Banyumas

\begin{tabular}{|c|c|c|c|c|}
\hline Karakteristik & Kasus & Kontrol & $\mathrm{n}$ & $\%$ \\
\hline \multicolumn{5}{|l|}{ Frekuensi Diare } \\
\hline \multirow[t]{2}{*}{ Tidak pernah } & 19 & 33 & 5 & 54,2 \\
\hline & & & 2 & \\
\hline \multirow[t]{2}{*}{ Jarang ( 1-3kali) } & 25 & 14 & 3 & 40,6 \\
\hline & & & 9 & \\
\hline Sering (>4 kali) & 4 & 1 & 5 & 5,2 \\
\hline \multicolumn{5}{|l|}{ Durasi Diare } \\
\hline \multirow[t]{2}{*}{ Tidak pernah } & 19 & 33 & 5 & 54,2 \\
\hline & & & 2 & \\
\hline \multirow[t]{2}{*}{ Tidak lama (<3 hari sembuh) } & 17 & 9 & 2 & 27,1 \\
\hline & & & 6 & \\
\hline \multirow[t]{2}{*}{ Lama (> 3 hari sembuh) } & 12 & 6 & 1 & 18,8 \\
\hline & & & 8 & \\
\hline \multicolumn{5}{|l|}{ Frekuensi ISPA } \\
\hline \multirow[t]{2}{*}{ Tidak pernah } & 9 & 21 & 3 & 31,3 \\
\hline & & & 0 & \\
\hline
\end{tabular}


JOURNAL OF NURSING PRACTICE AND EDUCATION VOL. 2 NO. 01, DESEMBER 2021

DOI: 10.34305/jnpe.v2i1.374
Ciptaan disebarluaskan di bawah Lisensi Creative Commons AtribusiNon Komersial-Berbagi Serupa 4.0

\begin{tabular}{lcccc} 
Jarang (1-3 kali) & 31 & 22 & 5 & 55,2 \\
Sering (>4 kali) & 8 & 5 & 1 & 13,5 \\
& & & 3 & \\
\hline $\begin{array}{l}\text { Durasi ISPA } \\
\text { Tidak pernah }\end{array}$ & 9 & 21 & 3 & 31,3 \\
Tidak lama (<6 hari sembuh) & 25 & 20 & 4 & 46,9 \\
Lama (>6 hari sembuh) & 14 & 7 & 5 & 21,9 \\
\multicolumn{1}{c}{ Total } & 48 & 48 & 9 & 100 \\
\hline
\end{tabular}

Sumber : data primer, 2020

\section{Pembahasan}

1) Frekuensi dan durasi (Diare)

Berdasarkan penelitian yang telah dilakukan, frekuensi diare dalam 6 bulan terakhir didapatkan hasil pada kelompok kasus lebih banyak di frekuensi jarang (1-3 serangan) dengan 25 responden, sedangkan pada kelompok kontrol paling banyak tidak pernah mengalami diare dengan jumlah 33 responden. Pada variabel durasi diare dalam 6 bulan terakhir didapatkan hasil pada kelompok kasus lebih banyak di durasi tidak lama (<3 hari sembuh) dengan 25 responden dan pada kelompok kontrol paling banyak tidak pernah mengalami diare dengan jumlah 33 responden. Hal ini menunjukkan bahwa anak yang mengalami stunting sering terkena penyakit infeksi dalam 6 bulan terakhir.
Penelitian ini sejalan dengan penelitian Batiro, et al. (2017) di Ethiopia menyimpulkan hasilnya terdapat hubungan diare dengan stunting. Balita dengan diare lebih sering mengalami stunting dibandingkan dengan balita yang tidak memiliki riwayat diare sebelumnya dalam dua minggu terakhir.

Hal ini juga sejalan dengan penelitian yang dilakukan oleh Desyanti \& Nindya (2017) juga menyatakan bahwa terdapat hubungan yang bermakna antara kejadian diare dengan kejadian stunting karena diare akut merupakan faktor risiko penyebab kejadian stunting. Riwayat diare yang terjadi secara lama dan sering dapat meningkatkan risiko terhadap kejadian stunting pada balita usia 24-59 bulan. 
JOURNAL OF NURSING PRACTICE AND EDUCATION VOL. 2 NO. 01, DESEMBER 2021

DOI: 10.34305/inpe.v2i1.374

2) Frekuensi dan durasi (ISPA)

Berdasarkan penelitian yang telah dilakukan, frekuensi ISPA dalam 6 bulan pada kelompok kasus dan kelompok kontrol lebih banyak di frekuensi jarang (1-3 serangan). Pada kelompok kasus dengan 31 responden dan pada kelompok kontrol dengan jumlah 22 responden.

Pada variabel durasi ISPA pada kelompok kasus lebih banyak di durasi tidak lama ( $<6$ hari sembuh) dengan 25 responden sedangkan pada kelompok kontrol paling banyak tidak pernah mengalami ISPA dengan jumlah 21 responden. Hal ini menunjukkan bahwa anak yang mengalami stunting sering terkena penyakit infeksi dalam 6 bulan terakhir.

Penelitian ini sejalan dengan Arini, et al. (2020) menyimpulkan hasilnya yaitu terdapat hubungan antara penyakit infeksi: ISPA dengan stunting. Pada balita perlu
Ciptaan disebarluaskan di bawah Lisensi Creative Commons AtribusiNon Komersial-Berbagi Serupa 4.0

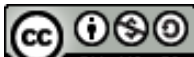

diberi ASI setidaknya selama enam bulan, oleh karena itu bila dilakukan kurang dari 6 bulan meningkat risiko stunting karena saluran pencernaan bayi belum sempurna, dan menjadi lebih rentan terhadap penyakit menular seperti ISPA. Dari hasil penelitian untuk karakteristik pendidikan ibu pada kelompok kasus yaitu masih rendah yaitu sebagian besar pendidikan lulusan SD.

Menurut Sinha, et al. (2018) menyimpulkan bahwa ISPA sangat erat kaitannya dengan pendidikan orang tua, karena dengan pengetahuan yang lebih tinggi mampu memahami bagaimana mencegah terjadinya penyakit infeksi pada balita.

Tingkat pengetahuan ibu tentang ASI eksklusif juga merupakan faktor penting yang terbukti dapat melindungi balita dari berbagai penyakit termasuk ISPA maupun diare.

2. Analisa Bivariat

Tabel 1.3 Hubungan Frekuensi dan Durasi dengan Kejadian Stunting di Wilayah Kerja Puskesmas Kebasen Kabupaten Banyumas

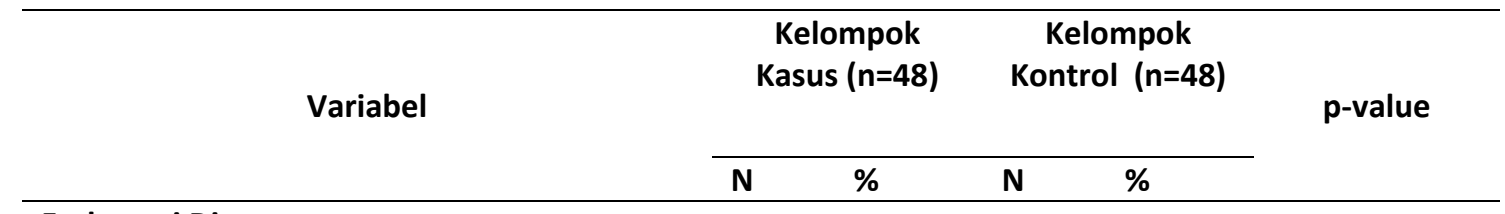


JOURNAL OF NURSING PRACTICE AND EDUCATION

VOL.2 NO. 01, DESEMBER 2021

DOI: 10.34305/inpe.v2i1.374
Ciptaan disebarluaskan di bawah Lisensi Creative Commons AtribusiNon Komersial-Berbagi Serupa 4.0

\begin{tabular}{llllll} 
Tidak pernah & 19 & 39,6 & 33 & 68,8 & 0,013 \\
Jarang ( 1-3 kali) & 25 & 52,1 & 14 & 29,2 & \\
Sering (>4 kali) & 4 & 8,3 & 1 & 2,1 & \\
\hline $\begin{array}{l}\text { Durasi Diare } \\
\text { Tidak pernah }\end{array}$ & 19 & 39,6 & 33 & 68,8 & 0,016 \\
& & & & & \\
Tidak lama (<3 hari sembuh) & 17 & 35,4 & 9 & 18,8 & \\
Lama (> 3 hari sembuh) & 12 & 25,0 & 6 & 12,5 & \\
\hline Frekuensi ISPA & & & & & \\
Tidak pernah & 9 & 18,8 & 21 & 43,8 & 0,030 \\
Jarang (1-3 kali) & 31 & 64,6 & 22 & 45,8 & \\
Sering (>4 kali) & 8 & 16,7 & 5 & 10,4 & \\
\hline Durasi ISPA & & & & & \\
Tidak pernah & 9 & 18,8 & 21 & 43,8 & 0,021 \\
Tidak lama (<6 hari sembuh) & 25 & 52,1 & 20 & 41,7 & \\
Lama (>6 hari sembuh) & 14 & 29,2 & 7 & 14,6 & \\
\hline Total & 48 & 100.0 & 48 & 100.0 & \\
\hline
\end{tabular}

**keterangan : Signifikansi pada p-value $0,05 n=96$

a. Hubungan Frekuensi dan Durasi

(Diare) dengan Kejadian Stanting di Wilayah Kerja Puskesmas Kebasen Kabupaten Banyumas

Berdasarkan hasil penelitian yang telah dilakukan bertujuan untuk mengetahui hubungan antara variabel bebas Frekuensi dan Durasi (Diare) menunjukkan bahwa untuk Frekuensi Diare nilai p-value sebesar 0,013 dan pada durasi diare nilai p-value sebesar 0,016. Dari hasil perhitungan tersebut dapat disimpulkan bahwa nilai $\mathrm{p}$ value $<0,05$ hal ini menunjukkan bahwa secara statistik terdapat hubungan yang bermakna antara Frekuensi dan Durasi (Diare) dengan status gizi balita: stunting.
Penelitian yang serupa dikemukakan oleh Wanda, et al. (2014) juga menyimpulkan bahwa anak dengan yang mempunyai riwayat penyakit diare berpeluang mengalami stunting sebesar 2.2 kali dan lebih besar jika dibandingkan dengan balita yang tidak mempunyai riwayat diare sebelumnya. Balita yang mengalami diare mengalami malabsorbsi zat serta durasi diare yang berjalan lama ( $>4$ hari) anak mengalami kehilangan zat gizi jika tidak di seimbangi dengan asupan yang seimbang akan menjadi gagal tumbuh. Diare yang terjadi dalam siklus yang lama dan sering pada saat balita usia dua tahun pertama kehidupannya nantinya dapat 
JOURNAL OF NURSING PRACTICE AND EDUCATION VOL. 2 NO. 01, DESEMBER 2021

DOI: $10.34305 /$ inpe.v2i1.374

berpengaruh terhadap terjadinya retardasi pertumbuhan. (Anwar, 2020)

Pada penelitian Wong, et al. (2014) di Malaysia juga menyimpulkan hasil bahwa sering sakit dan infeksifrekuensi penyakit anak (demam/diare/flu) merupakan salah satu faktor penentu penting menyebabkan malnutrisi pada balita.

Menurut Dinh, et al. (2016) stunting sangat dikaitkan dengan penyakit infeksi berulang merupakan infeksi yang paling penting menentukan.

Penelitian ini juga sesuai dengan Mugianti,et al. (2018) dimana riwayat penyakit infeksi memiliki hubungan dengan kejadian stunting dimana hasil penelitiannya anak yang menderita stunting satu bulan terakhir memiliki atau mengalami riwayat sakit berupa ISPA dan Diare.

b. Hubungan Frekuensi dan Durasi (ISPA) dengan Kejadian Stunting di Wilayah Kerja Puskesmas Kebasen Kabupaten Banyumas

Berdasarkan penelitian yang telah dilakukan yang bertujuan untuk mengetahui hubungan antara variabel bebas Frekuensi dan Durasi (ISPA) menunjukkan bahwa
Ciptaan disebarluaskan di bawah Lisensi Creative Commons AtribusiNon Komersial-Berbagi Serupa 4.0 untuk Frekuensi ISPA nilai $p$-value sebesar 0,016 dan pada durasi ISPA nilai p-value sebesar 0,021. Dari hasil perhitungan tersebut dapat disimpulkan bahwa nilai pvalue $<0,05$ hal ini menunjukkan bahwa secara statistik terdapat hubungan yang bermakna antara Frekuensi dan Durasi (ISPA) dengan status gizi balita: stunting.

Hasil penelitian ini juga sejalan dengan hasil penelitian oleh Nisa, (2020) dengan hasil penelitian yaitu yang mengalami riwayat penyakit infeksi ISPA $>5$ kali dalam 6 bulan dapat mengakibatkan balita stunting dikarenakan pada anak-anak yang menderita penyakit ISPA akan mengalami penurunan nafsu makan dan malabsorbsi nutrient dan apabila asupan nutrisi anak tidak seimbang dan memenuhi, maka ketidakseimbangan antara kebutuhan tubuh dan asupan makan akan terjadi. Penelitian ini juga sesuai dengan Kinyoki (2017) dengan kesimpulan di Somalia pada balita usia 6 sampai 59 bulan dengan hasil penelitian menunjukkan terdapat hubungan antara Infeksi Saluran Pernafasan Akut (ISPA) pada kejadian balita stunting.

Menurut Anmaru \& Laksono (2019) menunjukan hasil yang sama dengan penelitian ini yang menyimpulkan bahwa 
JOURNAL OF NURSING PRACTICE AND EDUCATION VOL. 2 NO. 01, DESEMBER 2021

DOI: $10.34305 /$ inpe.v2i1.374

penyakit infeksi memiliki hubungan yang signifikan dengan kejadian penyebab stunting. Penyakit infeksi memiliki efek terhadap pertumbuhan linier, penyakit infeksi dengan pertumbuhan linier antara lainnya adalah ISPA.

Berdasarkan penelitian yang telah dilakukan oleh Aobama (2020) dengan hasil penelitiannya yaitu balita yang memiliki riwayat penyakit infeksi lebih banyak dibandingkan dengan balita yang tidak memiliki penyakit infeksi. Balita rentan terkena penyakitdan jika penyakit infeksi dengan durasi lama dan frekuensi berulang akan mengakibatkan masalah pada status gizi anak yaitu stunting. Dampak gizi buruk pada balita adalah dapat terjadi gangguan pada pertumbuhan saat anak duduk di usia sekolah. Makanan dan penyakit dapat secara langsung menyebabkan gizi kurang pada balita. Anak yang hanya mendapatkan cukup makanan dan sering menderita sakit penyakit infeksi, dapat menderita gizi kurang (Cakrawati dan Mustika, 2012).

\section{Kesimpulan}

Kesimpulan yang didapat dari hasil penelitian yang telah dilakukan bahwa

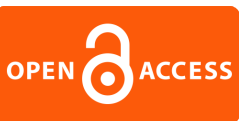

\section{Ciptaan disebarluaskan di bawah Lisensi Creative Commons Atribusi Non Komersial-Berbagi Serupa 4.0}

terdapat hubungan antara frekuensi dan durasi (Diare, ISPA) dengan kejadian stunting pada balita usia 24-59 bulan di Wilayah Kerja Puskesmas Kebasen.

\section{Daftar Pustaka}

Agung, S., Kurniawati, R.., Rahayu, S., \& Habibi, J. (2020). Hubungan status imunisasi dan riwayat penyakit infeksi dengan kejadian stunting pada balita: studi retrospektif. Journal of Midwifery, 8 (2), 1-9.

Angkat, A. H. (2018). Penyakit infeksi dan praktek pemberian MP-ASI terhadap Kejadian Stunting pada Anak Usia 12-36 Bulan di Kecamatan Simpang Kiri Kota Subussalam. Jurnal Dunia Gizi, 1 (1), 52 58.

Anmaru, Y. Y. R.., \& Laksono, B. (2019). The influencing factor analysis of stunting incidence in children aged 24-59 months at KedungJati Village. Public Health Perspective Journal, 4 (2), 116-121.

Anwar, C., Abdullah, M., \&Sasmita, V. (2020). Stunting dan faktor yang berhubungan studi kasus kontrol di wilayah kerja Puskesmas Baitussalam Kabupaten Aceh Besar. Journal of Healthcare Technology and Medicine, 6 (2), 988-998.

Arini, D., Nursalam, N., Mahmudah., \& Faradilah, I. (2020). The incidence of stunting, the frequency/duration of diarrhea and Acute Respiratory Infection in toddlers. Journal of Public Health Research, 9 (2), 117-119.

Aobama, P. J., \& Purwito, D. (2020). Determinan stunting pada balita di wilayah kerja Puskesmas Klampok 2

E-ISSN 2775-0663| 11 
JOURNAL OF NURSING PRACTICE AND EDUCATION

VOL. 2 NO. 01, DESEMBER 2021

DOI: 10.34305/inpe.v2i1.374

Kabupaten Banjar negara. Jurnal Keperawatan Muhammadiyah.

Azrimaidaliza., Anissa., Khairany, Y., Prativa, N., Adrianus, R., \& Salmah, M. P. (2019). Optimalisasi tumbuh kembang balita melalui promosi gizi seimbang di kecamatan koto tangah padang. Jurnal Ilmiah Pengabdian Kepada Masyarakat, 3 (2), 17-26.

Batiro, B., Demissie, T., Halala, Y., \& Anjulo, A. A. (2017). Determinants of stunting among children aged 6-59 months at Kindo Didayeworeda, Wolaita Zone, Southern Ethiopia: Unmatched case control study. PLOS ONE, 12 (12), 1-15.

Cakrawati dan Mustika NH, D. (2012). Bahan Pangan, Gizi, Dan Kesehatan.

Christin, Angelina. F., Perdana, A. A., \& H. (2018). Kejadian stunting balita umur 623 bulan di Provinsi Lampung. Jurnal Dunia Kesmas, 7 (3), 127-134.

Desyanti, C., \& Nindya, T. S. (2017). Hubungan riwayat penyakit diare dan praktik higiene dengan kejadian stunting pada balita usia 24-59 bulan. Amerta Nutr, 1 (3), 243-251.

Dinas Kesehatan Kabupaten Banyumas. (2019). Profil Kesehatan Kabupaten Banyumas Tahun 2019.

Dinh, D. M., Ramadass, B., Kattula, D., Sarkar, R., Braunstein, P., Tai A., et al. (2016). Longitudinal analysis of the intestinal microbiota in persistently stunted young children in South India. PLoS ONE, 11 (5), $1-18$.

Kemenkes, R. (2018). Situasi Balita Pendek (Stunting) Di Indonesia.
Ciptaan disebarluaskan di bawah Lisensi Creative Commons AtribusiNon Komersial-Berbagi Serupa 4.0

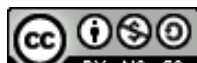

Kinyoki, D. K., Manda, S. O., Moloney, G. M., Odundo, E. O., Berkley, J. A., Noor, A. M., et al. (2017). Modelling the ecological comorbidity of acute respiratory infection ,diarrhoea and stunting among children under the age of 5 years in Somalia. International Statistical Review, 85 (1), 164-176.

Manggala, A. K., Kenwa, K. W., Kenwa, M. M., Sakti, A. A., \&Sawitri, A. A. (2018). Risk factors of stunting in children aged 24-59 months. Paediatrica Indonesiana, 58 (5), 205-212.

Maradzika, J., Makwara, I. P., \& Chipunza, S. (2016). Factors associated with stunting among children aged $0-59$ months in Harare City, Zimbabwe. International Journal of Child Health and Nutrition, 5 (1), 31-44.

Mugianti, S., Mulyadi, A., Anam, A. K.., \& Najah, Z. L. (2018). Faktor penyebab stunting usia 25-60 bulan di Kecamatan Sukorejo Kota Blitar. Journal of Ners and Midwifery, 5 (3), 268-278.

Nisa, N. (2020). Stunting Pada Balita di Puskesmas. Higeia Journal Of Public Health Research and Development, 4 (3), 595-605.

Noorhasanah, E., Tauhidah, N. I., \& Putri, M. (2020). Faktor-faktor yang berhubungan dengan kejadian stunting pada balita di wilayah kerja Puskesmas Tatah Makmur Kabupaten Banjar. Journal Of Midwivery and Reproduction, 4 (1), 13-20.

Rendradhuita, S. A. (2018). Gambaran Balita Stunting di Wilayah Kerja Puskesmas Wonosari II Gunungkidul Yogjakarta. STIKES Jenderal Achmad Yani Yogyakarta. http://repository.unjaya.ac.id/2339/2/SILV 
JOURNAL OF NURSING PRACTICE AND EDUCATION

VOL. 2 NO. 01, DESEMBER 2021

DOI: 10.34305/jnpe.v2i1.374

ANIA AZZOLA RENDRADUHITA $\% 281114186 \% 29$.pdf

Sinha, R. K., Dua, R., Bijalwan, V., Rohatgi, S., \& Kumar, P. (2018). Determinants of stunting, wasting, and underweight in five high-burden pockets of four Indian states.Indian Journal of Community Medicine, 43 (4), 279-83.

Wanda, L., Margawati, A., \&Rahfiludin, M. (2014). Faktor risiko stunting pada anak umur 6-24 bulan di kecamatan Penanggalan kota Subulussalam provinsi Aceh. Jurnal Gizi Indonesia, 3 (1), 37-45.

Welasih, B. D., \&Wirjatmadi, R. B. (2012). Beberapa faktor yang berhubungan dengan status gizi balita stunting. The Indonesian Journal of Public Health, 8 (3), 99-104.

Wong, H. J., Moy, F. M., \& N. S. (2014). Risk factors of malnutrition among preschool children in Terengganu, Malaysia: a case control study. BMC Public Health, 14 (785), 1-10.
Ciptaan disebarluaskan di bawah Lisensi Creative Commons Atribusi Non Komersial-Berbagi Serupa 4.0 